\title{
Studies on the amount and composition of digesta flowing through the duodenum of dairy cows. 2. Sites of net absorption of magnesium and calcium from the alimentary tract
}

\author{
A. Kemp' ${ }^{1}$ A. Th. van 't Klooster'2, P. A. M. Rogers ${ }^{3}$ and J. H. Geurink' \\ ${ }^{1}$ Institute for Biological and Chemical Research on Field Crops and Herbage (IBS), Wage- \\ ningen, the Netherlands \\ ${ }^{2}$ Department of Animal Physiology, Agricultural University, Wageningen, the Netherlands \\ ${ }^{3}$ The Agricultural Institute, Dunsinea, Castleknock, Dublin, Ireland
}

Accepted : 27 October 1972

\section{Summary}

1. The amounts of magnesium and calcium in the digesta flowing through the duodenum were measured direct in two cows fitted with re-entrant duodenal cannulas. A winter ration and a ration consisting of freshly mown herbage were given to both cows. Balance trials were carried out in the usual manner. Duodenal digesta were collected for $120 \mathrm{~h}$ in the middle of each balance period. In four other cows fitted with a T-piece cannula, the flow of duodenal digesta, $\mathrm{Mg}$ and $\mathrm{Ca}$ were estimated indirect by reference to poly(ethylene glycol) (PEG) and $\mathrm{Cr}_{2} \mathrm{O}_{3}$. Balance trials were carried out on these cows as above, and duodenal digesta were sampled every $2 \mathrm{~h}$ for $120 \mathrm{~h}$ in the middle of each balance period. 2. At normal $\mathrm{Mg}$ intakes there were no significant differences in net absorption of $\mathrm{Mg}$ proximal and distal to the duodenal cannula. At high $\mathrm{Mg}$ intakes net $\mathrm{Mg}$ absorption occurred mainly proximal to the duodenal cannula. Net $\mathrm{Ca}$ absorption was restricted to the intestines and a considerable net $\mathrm{Ca}$ secretion occurred proximal to the duodenal cannula. The amounts of chromium sesquioxide $\left(\mathrm{Cr}_{2} \mathrm{O}_{3}\right), \mathrm{Mg}$ and $\mathrm{Ca}$ which passed through the duodenum during the first $24 \mathrm{~h}$ of digesta collection were measured and were compared with the amounts which passed during each 120-h collection period. Recoveries of $\mathrm{Cr}_{2} \mathrm{O}_{3}$ averaged 85 and $98 \%$ at the end of 24 and $120 \mathrm{~h}$ respectively. The amounts of $\mathrm{Mg}$ and $\mathrm{Ca}$ which passed in the first $24 \mathrm{~h}$ were 99 and $96 \%$ of the mean amounts that passed during the 120-h collection. Experiments which combine the total collection of digesta for short periods (up to $24 \mathrm{~h}$ ) with a correction factor to adjust first day's flow of digesta to give $100 \%$ recovery of the indicator may involve a considerable error.

3. Reliable conclusions on the sites of net Mg absorption could not be drawn, as the error attached to the indirect estimates in these four cows was too great, with respect to the small total net absorption of $\mathrm{Mg}$. The results suggested, however, that $\mathrm{Ca}$ absorption was restricted to the intestines, with some secretion of $\mathrm{Ca}$ proximal to the duodenum.

\section{Introduction}

It is now generally agreed that hypomagnesaemia in the bovine arises by an inadequate absorption of magnesium from the elementary tract (Rook et al., 1958; Rook and Balch, 
1958; Kemp et al., 1960, 1961). The site of net absorption of magnesium from the alimentary tract of ruminants has been called in question recently. Studies with fistulated cows (Rogers and van 't Klooster, 1969) and with sheep (Grace, 1972) have indicated that the main site of magnesium absorption is proximal to the duodenum. This conclusion conflicts with that of other workers, who reported that magnesium was absorbed almost entirely from the small intestine in cattle (Perry et al., 1967) and sheep (Field, 1961). Smith (1962), working with fistulated calves, reported similar results for calves more than four months old, although he found that the large intestine was a very important absorption site in the very young non-ruminating calf. The reticulo-rumen of sheep was found to be unimportant, except at high magnesium concentrations in the rumen fluid (Stewart and Moodie, 1956; Care and van 't Klooster, 1965; Phillipson and Storry, 1965). Because of these conflicting conclusions, and because the validity of the sampling technique used by Rogers and van 't Klooster (1969) could not be proven in those experiments, the sites of absorption of $\mathrm{Mg}$ and $\mathrm{Ca}$ have been re-examined.

The present paper describes the results obtained by direct measurements in two cows fitted with re-entrant cannulas in the duodenum and by indirect estimates in four cows fitted with simple T-piece duodenal cannulas. This study was part of the experiment to assess the accuracy of indirect versus direct measurements of the flow of digesta and nutrients through the duodenum of cows (see van 't Klooster et al., 1972).

\section{Experimental}

Cows 3 and 4 were fitted with re-entrant duodenal cannulas, and cows 1, 2, 5 and 6 with T-piece duodenal cannulas. All cows had previously been fitted with rumen cannulas. During two experimental periods (I and III), two different rations were fed to each cow and full balance trials with separate collection of faeces and urine were carried out. Full details of the balance procedure, dosing with indicator (all cows), sampling procedure, analytical methods for PEG and $\mathrm{Cr}_{2} \mathrm{O}_{3}$ etc. are given in Part 1 (van 't Klooster et al., 1972). Details of the experimental cows, the rations given to the cows and the $\mathrm{Mg}$ supplementation (cows 1,2 and 3 only) are given in Tables 1 and 2 .

Duodenal collections were made over 5 continuous days $(120 \mathrm{~h})$ in the middle of each balance period. At $30 \mathrm{~min}$ past each hour about $700 \mathrm{ml}$ digesta from cows 1, 2, 5 and 6 were allowed to flow into a plastic 1-litre bottle. The digesta were mixed and sampled $(200 \mathrm{ml})$ and the remainder was returned to the duodenum. The samples were stored at $-25^{\circ} \mathrm{C}$ until required.

The concentration of $\mathrm{Mg}$ and $\mathrm{Ca}$ was determined in the acidified duodenal contents

Table 1. Age, body-weight, date of calving and type and situation of the duodenal cannula of the experimental cows. All animals were fitted with a rumen cannula.

\begin{tabular}{lllrl}
\hline $\begin{array}{l}\text { Cow } \\
\text { No }\end{array}$ & $\begin{array}{l}\text { Age } \\
\text { (years) }\end{array}$ & $\begin{array}{l}\text { Body-weight } \\
(\mathrm{kg})\end{array}$ & $\begin{array}{l}\text { Date of } \\
\text { calving }\end{array}$ & Type and situation of the cannulas used \\
1 & 5 & 537 & 6.1 .70 & Proximal duodenal cannula \\
2 & 5 & 503 & 28.2 .70 & Distal duodenal cannula \\
3 & 6 & 508 & 14.2 .70 & Re-entrant duodenal cannula in the distal duodenum \\
4 & 4 & 480 & 27.2 .70 & Re-entrant duodenal cannula in the distal duodenum \\
5 & 5 & 498 & 12.2 .70 & Proximal duodenal cannula \\
6 & 5 & 605 & 22.2 .70 & Distal duodenal cannula \\
\hline
\end{tabular}


A. KEMP, A. TH. VAN 'T KLOOSTER, P. A. M. ROGERS AND J. H. GEURINK

Table 2. Details of the experimental rations given to the cows.

\begin{tabular}{|c|c|c|c|c|c|c|}
\hline \multirow{2}{*}{$\begin{array}{l}\text { Exp. } \\
\text { No }\end{array}$} & \multirow{2}{*}{$\begin{array}{l}\text { Cow } \\
\text { No }\end{array}$} & \multirow{2}{*}{$\begin{array}{l}\text { Milk yield } \\
\text { (kg/day) }\end{array}$} & \multicolumn{3}{|c|}{ Rations (kg/day) } & \multirow{2}{*}{$\begin{array}{l}\text { MgO added } \\
\text { (g/day) }\end{array}$} \\
\hline & & & hay & $\begin{array}{l}\text { concen- } \\
\text { trates }\end{array}$ & $\begin{array}{l}\text { dry matter } \\
\text { intake }\end{array}$ & \\
\hline I & $\begin{array}{l}1 \\
2 \\
3 \\
4 \\
5 \\
6\end{array}$ & $\begin{array}{l}21.68 \\
19.16 \\
15.46 \\
16.00 \\
19.63 \\
26.21\end{array}$ & $\begin{array}{l}8.0 \\
8.0 \\
8.0 \\
7.0 \\
8.0 \\
8.0\end{array}$ & $\begin{array}{r}10.0 \\
8.0 \\
8.0 \\
8.0 \\
8.0 \\
11.0\end{array}$ & $\begin{array}{l}14.71 \\
13.40 \\
13.19 \\
12.27 \\
13.41 \\
15.85\end{array}$ & $\begin{array}{r}50 \\
50 \\
50 \\
0 \\
0 \\
0\end{array}$ \\
\hline II & $\begin{array}{l}1 \\
2 \\
3 \\
4 \\
5 \\
6\end{array}$ & $\begin{array}{l}18.63 \\
13.87 \\
10.40 \\
\\
16.77 \\
20.41\end{array}$ & \multicolumn{2}{|c|}{$\begin{array}{l}\text { All animals fed } \\
\text { on freshly } \\
\text { mown herbage } \\
\text { (early stage } \\
\text { of growth) }\end{array}$} & $\begin{array}{r}13.03 \\
10.22 \\
9.61 \\
\\
11.68 \\
13.08\end{array}$ & $\begin{array}{l}50 \\
50 \\
50 \\
\\
0 \\
0\end{array}$ \\
\hline III & $\begin{array}{l}1 \\
2 \\
3 \\
4 \\
5 \\
6\end{array}$ & $\begin{array}{l}16.54 \\
14.84 \\
11.78 \\
11.61 \\
15.11 \\
18.04\end{array}$ & \multicolumn{2}{|c|}{$\begin{array}{l}\text { All animals fed } \\
\text { on freshly } \\
\text { mown herbage } \\
\text { (older stage } \\
\text { of growth) }\end{array}$} & $\begin{array}{r}11.70 \\
10.91 \\
11.48 \\
9.37 \\
12.42 \\
11.35\end{array}$ & $\begin{array}{r}50 \\
50 \\
50 \\
0 \\
0 \\
0\end{array}$ \\
\hline
\end{tabular}

and in the ashed feeding stuffs and faeces by atomic absorption flame spectrophotometry. The standards used and the samples were diluted with $\mathrm{SrCl}_{3}$ solution $(10 \mathrm{~g} / \mathrm{litre})$ after precipitation of sulphate.

The flow of digesta through the duodenum was measured directly (120 continuous hours in each experiment) in cows 3 and 4 . The concentrations of $\mathrm{Mg}$ and $\mathrm{Ca}$ in proportional samples $(2 \%)$ were estimated for all samples from the even hours and in bulk samples for each day (day samples) which were composed from twelve samples from the odd hours of each day. The calculation of the amounts of $\mathrm{Mg}$ and $\mathrm{Ca}$ passing through the duodenum was based on these analyses.

The flow of digesta, $\mathrm{Mg}$ and $\mathrm{Ca}$ through the duodenum of cows $1,2,5$ and 6 was estimated indirectly by reference to PEG and $\mathrm{Cr}_{2} \mathrm{O}_{3}$ as follows. Fixed amounts of each sample for the even hours were combined to form one bulk sample for each cow for each collection period of five days. Each bulk sample, therefore, was composed of sixty samples (van 't Klooster and Rogers, 1969). Samples from each odd hour were bulked to form five-day samples per cow. Analytical results of these day samples were used to estimate the day-to-day variation between the bulked samples. The quantities of $\mathrm{Mg}$ and $\mathrm{Ca}$ that passed through the duodenum of cow 1,2, 5 and 6 were calculated for the even and odd hours separately as:

$$
\text { total } \mathrm{Mg} \text { or } \mathrm{Ca} / 12 \mathrm{~h}=\frac{\text { dose of indicator } / 12 \mathrm{~h}}{\text { content of indicator } / \mathrm{kg} \text { digesta }} \times \mathrm{g} \mathrm{Mg} \text { or } \mathrm{Ca} / \mathrm{kg} \text { digesta }
$$

where the digesta samples used for analysis were the bulk samples of the even hours and odd hours, respectively. Agreement between estimates for the even and odd hours was good. The sum of both estimates represents the total amount of magnesium or calcium that passed through the duodenum per day. By comparing the amounts of $\mathrm{Mg}$ and $\mathrm{Ca}$ 
AMOUNT AND COMPOSITION OF DIGESTA IN THE COW'S DUODENUM. 2

ingested and the amounts calculated to pass through the duodenum with those excreted in the faeces, the net absorption proximal and distal to the duodenal cannulae could be estimated.

\section{Results}

The availability and balance of $\mathrm{Ca}$ and $\mathrm{Mg}$

Table 3 shows the mean daily intakes and excretions of $\mathrm{Ca}$ and $\mathrm{Mg}$ and the concentrations of $\mathrm{Mg}$ in plasma of the six cows on a winter ration and on a ration of freshly mown herbage. Blood samples were taken at the end of each experimental period. The availability of $\mathrm{Ca}$ averaged 20 and $21 \%$ and the availability of $\mathrm{Mg}$ averaged 15 and $21 \%$, respectively. (Availability $=\%$ of intake not excreted with the faeces and corrected for removal of digesta samples.)

The secretion of $\mathrm{Ca}$ and $\mathrm{Mg}$ in milk was determined mainly by the milk yield, as one might expect. The $\mathrm{Ca}$ excretion in urine was low in both experiments. The $\mathrm{Ca}$ balances appeared to be normal for the stages of lactation.

Excretion of $\mathrm{Mg}$ in urine was lowest in cows 4 and 5 on the grass ration and coincided with the lowest plasma $\mathrm{Mg}$ levels measured in these experiments. Plasma $\mathrm{Mg}$ levels remained normal in the other cows and in all 6 cows on the winter ration. This suggests that the amount of available $\mathrm{Mg}$ was adequate to meet the requirements (Kemp et al., 1960), except in cows 4 and 5 , that were given the herbage ration. The variation in the $\mathrm{Mg}$ balances was somewhat greater than in other trials at this laboratory (Kemp et al., 1960) but, taking into account the greater fluctuation in daily faeces production in the present experiments, these balances are acceptable.

Sites of Mg absorption as determined by direct and indirect measurements in the same cows. Table 4 shows the mean intake of $\mathrm{Mg}$, the rate of passage of digesta, the amount of $\mathrm{Mg}$ calculated to pass through the duodenum, the net amounts absorbed proximal to the re-entrant duodenal cannulas, the amount excreted in the faeces and the net amounts absorbed distal to the duodenal cannulas. Results are given for the net absorption measured direct and estimated indirect.

A significant absorption of magnesium occurred proximal to the duodenal cannulas in both cows in Expts I and III. Distal to the duodenal cannula there was also a significant absorption in cow 4 given the winter ration and in cows 3 and 4 given the herbage ration. The net obsorption proximal to the duodenal cannulas in both experiments was greater in cow 3 with extra magnesium than in cow 4 with a normal magnesium intake. The differences in net absorption between the cows on the two levels of magnesium intake appeared to be less distal to the duodenal cannulas. The higher net absorption in the cow with the high magnesium intake took place mainly proximal to the duodenal cannula. On the normal magnesium intake there were no significant differences in net absorption proximal and distal to the duodenal cannulas.

It has been shown (van 't Klooster et al., 1972) that indirect estimates of the flow of digesta through the duodenum gave good agreement with direct measurements. Moreover, there were no significant differences between the $\mathrm{Mg}$ concentration of the proportional and the non-proportional samples of digesta. However, a relatively small difference in total flow of digesta, whether estimated direct or by reference to PEG or $\mathrm{Cr}_{2} \mathrm{O}_{3}$ is associated with a large error in the estimates of the net amounts of $\mathrm{Mg}$ and $\mathrm{Ca}$ absorbed proximal or distal to the cannula. This is most noticeable for Mg. For instance, in cow 3, Exp. I, a 
A. KEMP, A. TH. VAN 'T KLOOSTER, P. A. M. ROGERS AND J. H. GEURINK

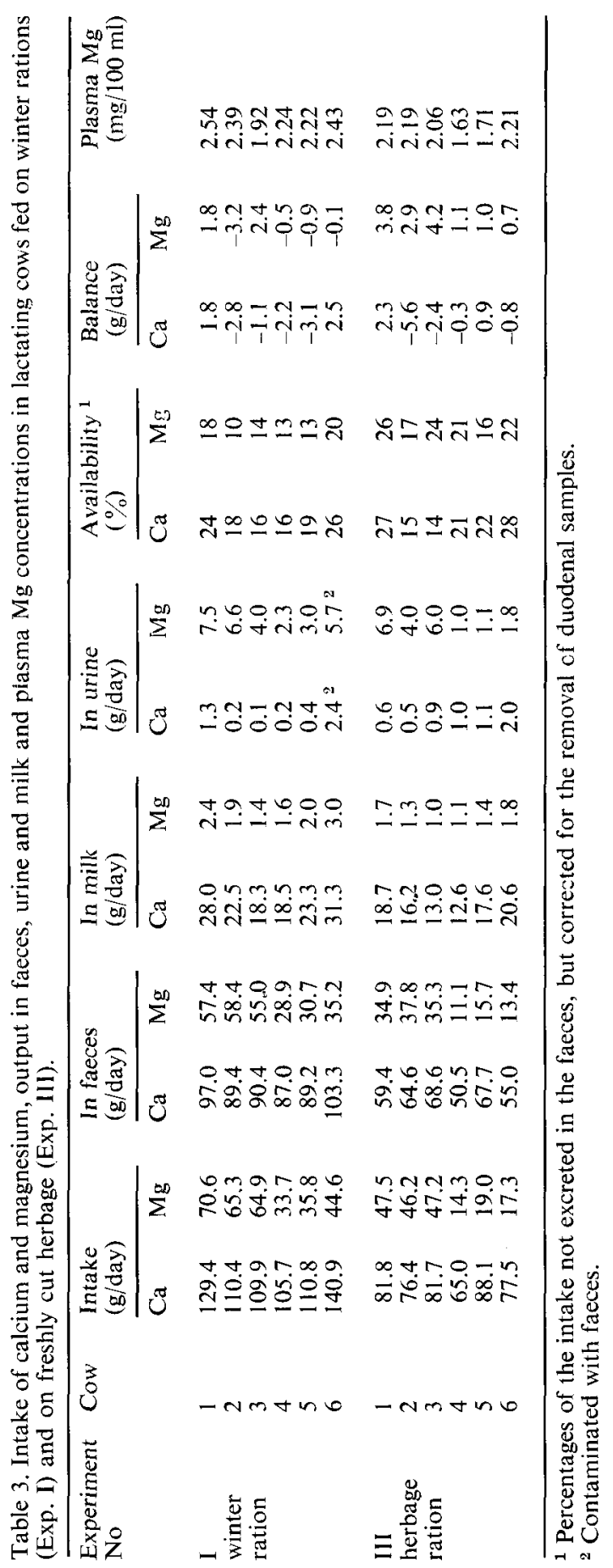


AMOUNT AND COMPOSITION OF DIGESTA IN THE COW'S DUODENUM. 2

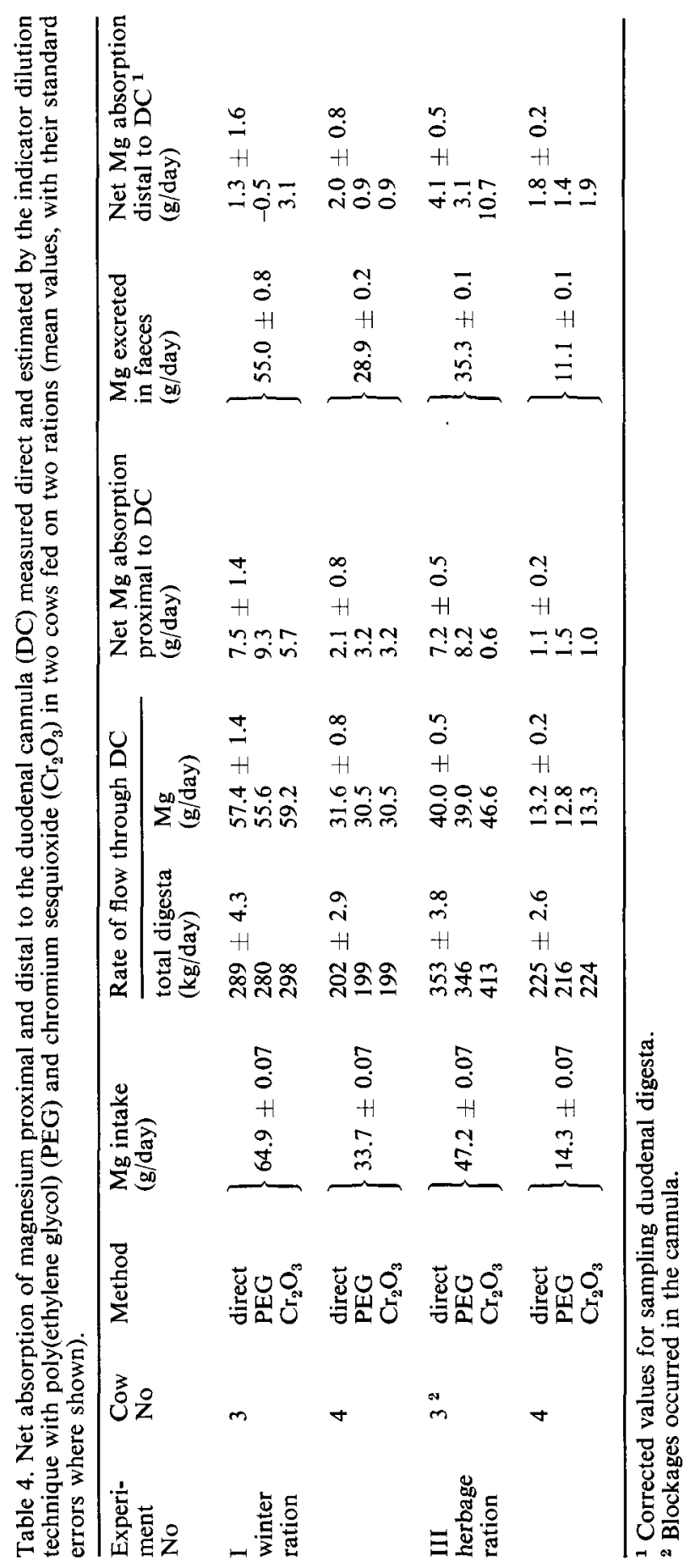

Neth. J. agric. Sci, 21 (1973) 
A. KEMP, A. TH. VAN 'T KLOOSTER, P. A. M. ROGERS AND J. H. GEURINK

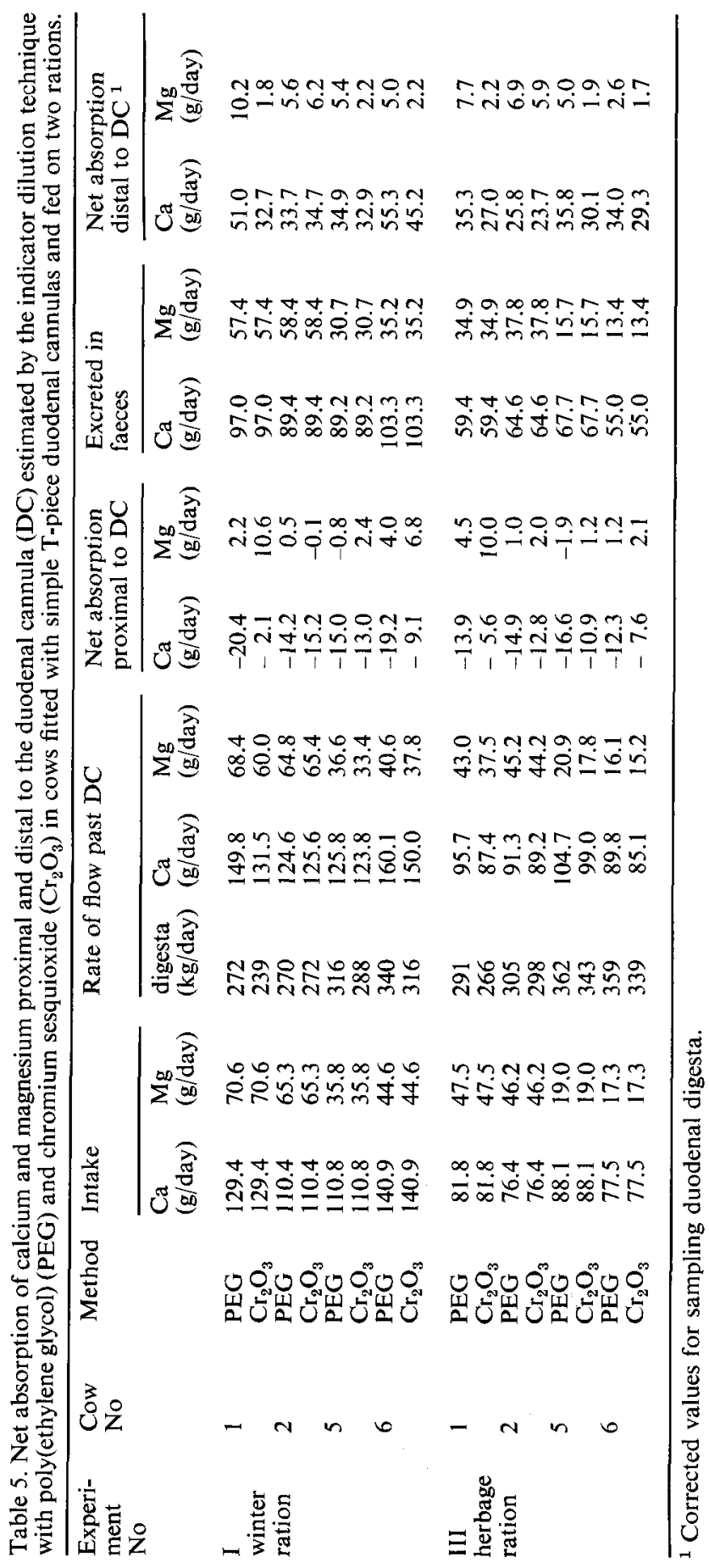


AMOUNT AND COMPOSITION OF DIGEST IN THE COW'S DUODENUM. 2

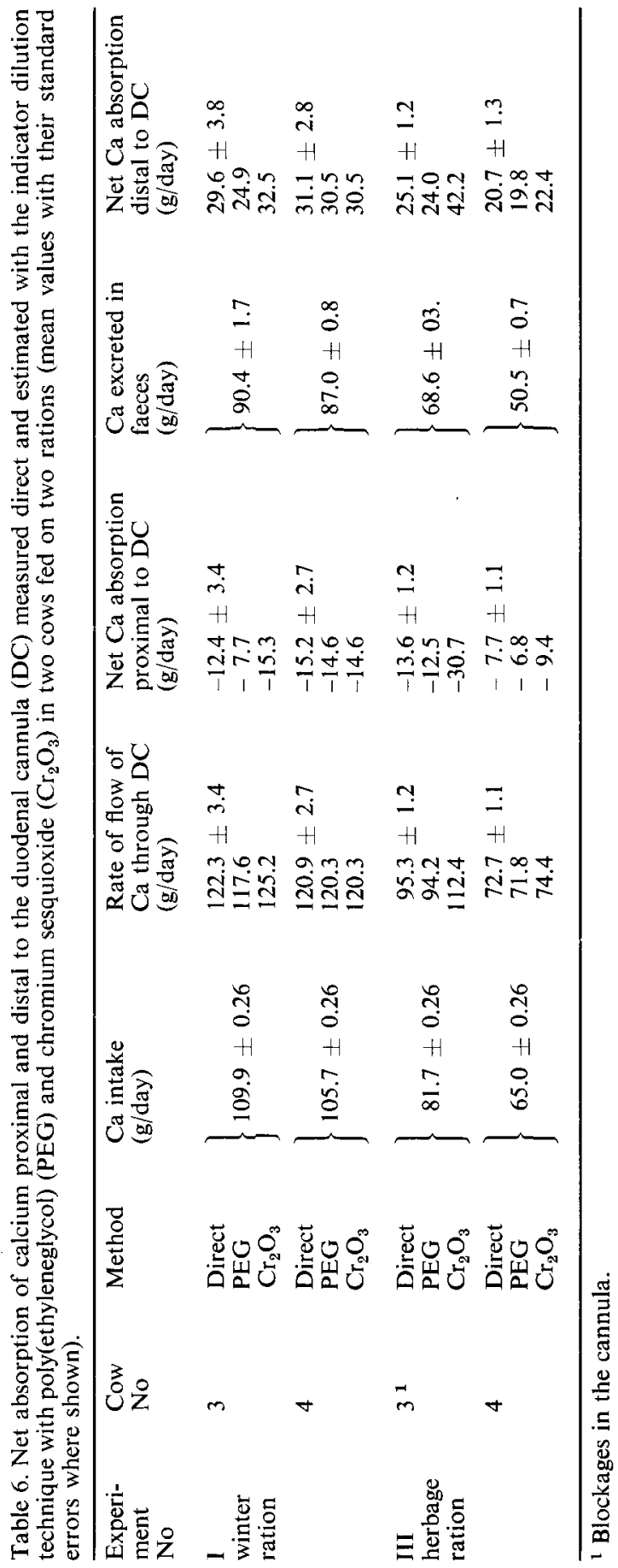

Neth. J. agric. Sci. 21 (1973)

51 
small difference $(3 \%)$ between the estimates of digesta flow measured direct and by reference to $\mathrm{PEG}$ resulted in a difference of $24 \%$ in the estimate of $\mathrm{Mg}$ absorbed proximal to and of more than $100 \%$ distal to the duodenal cannula.

The peculiar values for the amounts of $\mathrm{Mg}$ calculated to pass the duodenum by reference to $\mathrm{Cr}_{2} \mathrm{O}_{3}$ in cow 3, given the herbage ration, were caused by extremely low $\mathrm{Cr}_{2} \mathrm{O}_{3}$ concentrations in the digesta on one of the five days of the duodenal collection. The low passage of $\mathrm{Cr}_{2} \mathrm{O}_{3}$ in this experiment may have been due to abomasal distension resulting from the 'blockages of the cannula occurring in this instance (van 't Klooster et al., 1972).

The mean recoveries of $\mathrm{Cr}_{2} \mathrm{O}_{3}$ and PEG during the first $24 \mathrm{~h}$ of each 120 -h collection of duodenal digesta were 85 and $95 \%$, respectively. The mean amounts of $\mathrm{Mg}$ which were calculated by direct measurement to pass in the same $24 \mathrm{~h}$ equaled the mean daily amounts for the 120-h periods. The duodenal recovery of $\mathrm{Cr}_{2} \mathrm{O}_{3}$ and PEG over the 120-h periods averaged 100.3 and $98.3 \%$, respectively (van 't Klooster et al., 1972). It follows that a correction of the amount of $\mathrm{Mg}$ which was measured direct over the first $24 \mathrm{~h}$ to give a theoretical recovery of $100 \%$ of $\mathrm{Cr}_{2} \mathrm{O}_{3}$ would result in much higher estimates of the amount of $\mathrm{Mg}$ passing through the duodenum than was found by direct measurements over $120-\mathrm{h}$ periods.

Sites of Mg absorption as examined by indirect measurements in cows with T-piece duodenal cannulas

Table 5 gives for cows 1, 2, 5 and 6 the results as shown in Table 4 for the cows with reentrant cannulas. For some reason unknown, the estimates of flow based on the PEG content of the duodenal digesta were higher in most instances than the estimates of flow based on the $\mathrm{Cr}_{2} \mathrm{O}_{3}$ content of the digesta. Consequently, the estimates of the amounts of $\mathrm{Mg}$ passing in the digesta showed the same differences. The average net absorption of $\mathrm{Mg}$ from the entire tract in these cows was $7.4 \mathrm{~g} / \mathrm{day}$. By reference to PEG, the mean net absorptions proximal and distal to the duodenum were 1.3 and $6.1 \mathrm{~g} /$ day, respectively; by reference to $\mathrm{Cr}_{2} \mathrm{O}_{3}$, the values were 4.4 and $3.0 \mathrm{~g} /$ day, respectively. It was not possible to decide which of the two indicators was the more likely to yield the more accurate result in these cows. When the two indicator techniques were considered as duplicates the net absorptions of $\mathrm{Mg}$ proximal and distal to the cannulas were about 2.9 and $4.5 \mathrm{~g} / \mathrm{day}$, respectively. Because of the considerable variation between the two indicators in respect of the small amounts of $\mathrm{Mg}$ absorbed, reliable conclusions on the sites of $\mathrm{Mg}$ absorption could not be drawn from these results.

\section{Sites of Ca absorption}

Table 5 shows the net amounts of $\mathrm{Ca}$ absorbed by reference to $\mathrm{PEG}$ and $\mathrm{Cr}_{2} \mathrm{O}_{3}$ in cows 1, 2, 5 and 6. Table 6 shows the amounts absorbed by cows 3 and 4, estimated direct and also by reference to PEG and $\mathrm{Cr}_{2} \mathrm{O}_{3}$. The general results in cows 1, 2, 5 and 6 suggested that about $13 \mathrm{~g} \mathrm{Ca}$ /day was secreted proximal to the duodenal cannulas and about $35 \mathrm{~g} /$ day was absorbed from the intestines. These amounts agree with the amounts measured directly in cows 3 and 4 . Absorption of calcium proximal to the duodenal cannulas can not be excluded, but net absorption is restricted to the intestines.

\section{Discussion}

The present results showed no significant difference between the availability of $\mathrm{Mg}$ for cows given a supplement of $\mathrm{MgO}$ compared with cows not given the supplement. This 
agrees with earlier conclusions (Kemp et al., 1961). The results also show that the availability of $\mathrm{Mg}$ may be less in a winter ration than in spring herbage.

The results of the direct measurements in cows 3 and 4 , fitted with re-entrant cannulas in the duodenum, showed that significant net absorption of $\mathrm{Mg}$ occurred from the stomachs as well as from the intestines. With normal $\mathrm{Mg}$ intakes there were no significant differences between the two sites, whereas with high $\mathrm{Mg}$ intakes the stomachs were much more important than the intestines. This agrees with earlier experiments of Rogers and van 't Klooster (1969) and also with the findings of Kemp (1959) and Kemp et al. (1963), that plasma $\mathrm{Mg}$ concentrations in hypomagnesaemic cows rise within $2 \mathrm{~h}$ after dosing with $40 \mathrm{~g} \mathrm{MgO}$, or more, in Mg-containing cakes.

The volume of saliva, gastric juice, bile and pancreatic juice secreted in these cows would amount to about 300 litres and would add $1.5-2.0 \mathrm{~g} \mathrm{Mg}$ to the digesta, proximal to the duodenal cannula. Therefore the total absorption of $\mathrm{Mg}$ proximal to the sampling point would be increased by this amount.

The recovery of PEG and $\mathrm{Cr}_{2} \mathrm{O}_{3}$ from duodenal digesta of sheep (van 't Klooster et al., 1969) and cows (van 't Klooster et al., 1972) was almost complete, and indirect estimates of digesta flow based on PEG agreed very well with those based on $\mathrm{Cr}_{2} \mathrm{O}_{3}$. Furthermore, the estimate of duodenal digesta flow in the earlier work with cows (van 't Klooster and Rogers, 1969) showed only a 3\% difference between the values based on PEG and those based on $\mathrm{Cr}_{2} \mathrm{O}_{3}$. In those experiments, the means of the values based on both indicators were used and the results indicated that net absorption of $\mathrm{Mg}$ occurred mainly from the stomachs. In the present experiments, with the indicator dilution technique in the four cows fitted with simple T-piece cannulas, the estimates of the duodenal flow of digesta, $\mathrm{Mg}$ and $\mathrm{Ca}$, based on PEG, were about $6 \%$ higher than those based on $\mathrm{Cr}_{2} \mathrm{O}_{3}$. This difference between the two indicators resulted in a large error attached to the small amounts of $\mathrm{Mg}$ absorbed and does not allow definite conclusions on the sites of $\mathrm{Mg}$ absorption to be drawn from these results.

The errors attached to direct measurement of the flow of digesta and nutrients through the duodenum are such that the errors attached to estimates of net absorption proximal or distal to the cannula are relatively large, particularly when the amounts absorbed are small. As the net absorption increases, for instance with $\mathrm{Mg}$ in cows receiving extra $\mathrm{MgO}$, the reliability of the estimates of segmental absorption increases. The same comments apply with even more force to indirect estimate made by the indicator dilution technique. The cause of the discrepancy between the PEG and $\mathrm{Cr}_{2} \mathrm{O}_{3}$ results in these four cows could not be determined.

The present findings that net absorption of $\mathrm{Ca}$ occurs mainly or exclusively from the intestines is in agreement with earlier conclusions (Smith, 1962; Cragle et al., 1964; Phillipson and Storry, 1965; Yan and Thomas, 1965; Perry et al., 1967; van 't Klooster, 1967; Rogers and van 't Klooster, 1969). The results suggested that the net secretion proximal to the duodenal cannulas was about $13 \mathrm{~g} \mathrm{Ca} /$ day. Secretion products would add about $6 \mathrm{~g}$ /day if their Ca content is similar to that of sheep (Storry, 1960), but it is possible that the content is higher in cows. However, the daily endogenous faecal loss of Ca was estimated to be about $20 \mathrm{mg} / \mathrm{kg}$ body weight in cows (Visek et al., 1953; Hansard et al., 1954; Conrad et al., 1956). In our experiments, the endogenous faecal loss of Ca would have been about $10 \mathrm{~g} /$ day, on this basis. If one assumes that the availability of endogenous $\mathrm{Ca}$ in the digesta is the same as that of dietary $\mathrm{Ca}$, and that most of the endogenous $\mathrm{Ca}$ is secreted proximal to the duodenal cannula, this would result in a secretion of over $12 \mathrm{~g}$ $\mathrm{Ca}$ /day proximal to the cannula.

A negative relationship between the calcium intake and the availability of $\mathrm{Ca}$ can be 
deduced from several experiments (Duncan, 1958). The intake of $\mathrm{Ca}$ and the daily milk yields in cows given the herbage ration were considerably lower than in those giving the winter ration. The combination of lower $\mathrm{Ca}$ intake with lower milk yield may explain the lack of difference in $\mathrm{Ca}$ availability between Exp. I and III because a lower milk yield goes with a lower availability.

Several workers have taken the low recovery of the indicators over the first $24-\mathrm{h}$ period of collection as an indication of a depressed flow rate. Therefore, they adjusted the measured flow rate to a value which would give a theoretical $100 \%$ recovery of the indicator on the assumption that the rate of passage of nutrient and indicator are depressed in the same way. In cows 3 and 4 the flow of $\mathrm{Ca}$ and $\mathrm{Mg}$ during the first $24 \mathrm{~h}$ was adjusted to $100 \%$ recovery of $\mathrm{Cr}_{2} \mathrm{O}_{3}$ and considerable differences were noted between the adjusted values and the mean flow of $\mathrm{Ca}$ and $\mathrm{Mg}$, which were measured directly over 5-day periods. The technique combining short periods of direct measurement with adjustments to $100 \%$ recovery of indicator saves much of the labour and tedium involved in total collection of digesta over long periods. However, the errors involved are often large and the basic assumption that indicator and nutrient flow are correlated has been shown to be invalid, both in these and in previous experiments (van 't Klooster et al., 1969).

In the present experiments the potential difference between blood and lumen of the reticulo-rumen was found to be about $25 \mathrm{mV}$ in cows given the winter ration and about $40 \mathrm{mV}$ in cows given the herbage ration for all six cows. If a $\mathrm{Mg}$ ion concentration in blood is assumed to be $1.2 \mathrm{meq} / \mathrm{litre}$ it can be calculated from the formula of Nernst that for passive absorption of $\mathrm{Mg}$ from the reticulo-rumen the concentration of $\mathrm{Mg}$ ions in the rumen fluid would have to exceed $8 \mathrm{meq} / \mathrm{litre}$ in the rumen fluid in Exp. I and $16 \mathrm{meq} /$ litre in Exp. III. The concentrations of $\mathrm{Mg}$ in rumen fluid on the day following the end of the duodenal collection period (rumen fluid samples taken at four different times between the morning and evening feed) were found to be lower than those necessary for a passive transport of $\mathrm{Mg}$, except in the cows receiving extra Mg in Exp. I. On a few occasions the levels reached $16 \mathrm{meq} /$ litre in these cows.

For a passive transport of $\mathrm{Mg}$ from the omasum to blood, even higher concentrations of $\mathrm{Mg}$ ions would be necessary, since the potential difference between blood and omasal contents was found to be about $20 \%$ greater than the difference between blood and rumen contents. This raises the question of the mechanisms underlying the absorption process of $\mathrm{Mg}$ from the forestomachs.

\section{References}

Care, A. D. \& A. Th. van 't Klooster, 1965. In vitro transport of magnesium and other cations across the wall of the gastrointestinal tract of sheep. J. Physiol., Lond. 177: 174.

Conrad, H. R., S. L. Hansard \& J. W. Hibbs, 1956. Studies on milk fever in dairy cows. V. The effect of massive oral doses of vitamin D on absorption, excretion, retention and blood levels of calcium and phosphorus. J. Dairy Sci. 39: 1697.

Cragle, R. G., J. K. Miller \& P. T. Chandler, 1964. Gastro-intestinal sites of absorption and secretion of $\mathrm{Ca}, \mathrm{P}, \mathrm{Zn}$ and $\mathrm{I}$ in dairy cattle. Symp. on the use of radioisotopes in animal nutrition and Physiology, Prague, p. 23-27. International atomic energy agency F.A.O.

Duncan, D. L., 1958. The interpretation of studies of calcium and phosphorus balance in ruminants. Nutr. Abstr. Rev. 28: 695.

Field, A. C., 1961. Distribution of $\mathrm{Mg}^{28}$ in the gastro-intestinal tract and tissues of sheep. Br. $J$. Nutr. 15: 349.

Grace, N. D., 1972. Influence of feeding regimen and protein supplementation on the sites of net absorption of magnesium in sheep. Br. J. Nutr. 27: 51 .

Hansard, S. L., C. L. Comar \& M. P. Plumlee, 1954. The effests of age upon calcium utilization and maintenance requirements in the bovine. J. Anim. Sci. 13:25. 
Kemp, A., 1959. Landbouwkundige aspecten van het kopziektevraagstuk. Tijdschr. Diergeneesk. 84: 331.

Kemp, A., W. B. Deijs, O. J. Hemkes \& A. J. H. van Es, 1963. Conference on hypomagnesaemia (London), p. 23. London, British Veterinary Association.

Kemp, A., W. B. Deijs, O. J. Hemkes \& A. J. H. van Es, 1961. Hypomagnesaemia in milking cows: intake and utilization of magnesium from herbage by lactating cows. Neth. J. agric. Sci. 9: 134.

Kemp, A., J. H. Geurink \& H. J. Immink, 1963. Het effect van magnesiumtoediening op de magnesiumgehalten van het bloedserum bij melkkoeien met hypomagnesemie. Tijdschr. Diergeneesk. 88: 1172.

Klooster, A. Th. van 't, 1967. De toestand van calcium, magnesium en enkele andere mineralen in darminhoud en mest van herkauwers in verband met hun rasorptie. Medzd. LandbHogesch. Wageningen 67-5.

Klooster, A. Th. van 't, A. Kemp, J. H. Geurink \& P. A. M. Rogers, 1972. Studies on the amount and composition of digesta flowing through the duodenum of dairy cows. 1. Rate of flow of digesta measured direct and estimated indirect by the indicator dilution technique. Neth. J. agric. Sci. 20: 314-324.

Klooster, A. Th. van 't \& P. A. M. Rogers, 1969. The rate of flow of digesta and the net absorption of dry matter, organic matter, ash, nitrogen and water. Meded. LandbHogesch. Wageningen 69-11: 3 .

Klooster, A. Th. van 't, P. A. M. Rogers \& H. R. Sharma, 1969. Observations on the rate of flow of digesta through the duodenum of sheep on the recovery of polyethylene glycol and chromium sesquioxide from duodenal contents. Neth. J. agric. Sci. 17: 60 .

Perry, S. C., R. G. Cragle \& J. K. Miller, 1967. Intestinal distribution of Ca, $\mathrm{Mg}, \mathrm{Na}, \mathrm{K}$ and $\mathrm{N}$ in calves fed three rations. J. Nutr. 93: 283.

Phillipson, A. T. \& J. E. Story, 1965. The absorption of calcium and magnesium from the rumen and small intestine of the sheep. J. Physiol., Lond. 181: 130.

Rogers, P. A. M. \& A. Th. van 't Klooster, 1969. The fate of $\mathrm{Na}, \mathrm{K}, \mathrm{Ca}, \mathrm{Mg}$ and $\mathrm{P}$ in the digesta. Meded. LandbHogesch. 69-11: 26.

Rook, J. A. F., C. C. Balch \& C. Line, 1958. Magnesium metabolism in the dairy cow. I. Metabolism on stall rations. J. agric. Sci. 51: 189.

Rook, J. A. F. \& C. C. Balch, 1958. Magnesium metabolism in the dairy cow. II Metabolism during the spring grazing season. J. agric. Sci. 51: 199.

Smith, R. H., 1962. Net exchange of certain inorganic ions and water in the alimentary tract of the milk-fed calf. Biochem. J. 83:151.

Stewart, J. \& E. W. Moodie, 1956. The absorption of magnesium from the elementary tract of sheep. J. comp. Path. 66: 10.

Story, J. E., 1960. Calcium and magnesium contents of various secretions entering the digestive tract of sheep. Nature, Lond. 190: 1197.

Visek, W. J., R. A. Monroe, E. W. Swanson \& C. L. Comar, 1953. Calcium metabolism in dairy cows as studied with $\mathrm{Ca}^{45}$. J. Dairy Sci. 36: 373 .

Yang, M. G. \& J. W. Thomas, 1965. Absorption and secretion of some organic and inorganic constituents and the distribution of these constituents throughout the alimentary tract of young calves. J. Nutr. 87: 444. 